\title{
Conceptual features of the circular economy and the possibilities of its formation using smart systems
}

\author{
Elena Avdeeva ${ }^{1, *}$, Tatiana Davydova ${ }^{1}$, Tatyana Makeeva $^{1}$ and Alina Korovkina ${ }^{1}$ \\ Voronezh State Technical University", Moscovskiy prospect, 14, Voronezh, 394026, Russia
}

\begin{abstract}
Development, leading to the depletion of resources, in modern conditions is not seen as long-term and sustainable. Accordingly, national strategies for security, long-term and territorial development of the countries of the world are being developed in accordance with the existing goals of sustainable development. This study examines the relationship of sustainable development with the goals of countries in the framework of the orientation towards the introduction of new models of economic development - a green and circular economy. The highly specialized applications of the noted models are considered, the ambiguity of the possibilities and results of their practical implementation is noted, depending on the level of development of states, the level of their incomes, social or economic priorities of their development. The advantages and disadvantages of the circular economy model are summarized.
\end{abstract}

\section{Introduction}

Sustainable development, which is the basis for the formation of development strategies for modern states, is defined as development that meets the needs of the present without compromising the ability of future generations to meet their own needs [1]. The Sustainable Development Goals (SDGs), which correspond to 169 targets, were adopted in the document "The 2030 Agenda for Sustainable Development" by 193 UN member states at the UN General Assembly summit in September 2015 and are designed for 15 years, until 2030 [2]. Accordingly, the environmental and resource components are especially significant: development that leads to the depletion of natural resources cannot be sustainable in the long term. In this regard, in the world theory and practice, new models of economic development focused on environmental welfare are becoming more widespread [3]. These include green economy, low-carbon economy, blue economy, green growth, bioeconomy, circular or circular, cyclical, restoration economy (circular economy) [4-7], and its variations, for example, circular bioeconomy [6,7]. Both at the macro level and at the level of individual enterprises, in long-term plans and reporting, an increasingly

\footnotetext{
*Corresponding author: avdeeva_ea@mail.ru
} 
important position is given to adherence to sustainable development goals. Policies that are in line with the basic principles of a circular economy are being developed and implemented especially actively. The principles are focused on conserving resources during their long-term use through recovery and reuse.

\section{Materials and Methods}

The analysis of existing points of view showed that the depletion of resources and environmental degradation caused by globalization are highlighted as a prerequisite for an orientation towards the development of a circular economy [4-6]. Accordingly, the conceptual model of a circular economy presupposes the maximum reduction in the volume of waste generated with all possible government support for relevant initiatives, including in the sectoral and regional sections. The practice of energy and environmental labeling of products, "green" public procurement, and the expansion of producer responsibility is used [9]. The diversity of the aspectual development of the circular economy is emphasized by the author's positions. Thus, it is noted that the circular economy tends to form, first of all, economic and environmental values in all spheres of human life [6-8].

At the same time, the circular economy is assumed to be rather narrowly oriented in comparison with the green economy, which takes into account the social component to a greater extent, and is focused on improving the welfare of the population as a whole. For example, there is an opinion that the issues of studying the circular economy are rarely combined with the issues of studying the features of human resource management [10].

It is clear that the global economy of mass production and mass consumption has generated a large amount of civilization wastes and caused many negative externalities such as climate change, plastic pollution of the marine environment, rainforests and destruction of biodiversity (Figure 1).

According to UN estimates, the population is growing by 83 million annually. This means that 83 million people are more dependent on the share of the world's resources. Our nature can only revive in 1.5 years what will be consumed by the world's population in a year. We consume irresponsibly and excessively, we need a new way of thinking and a new economic model [11].

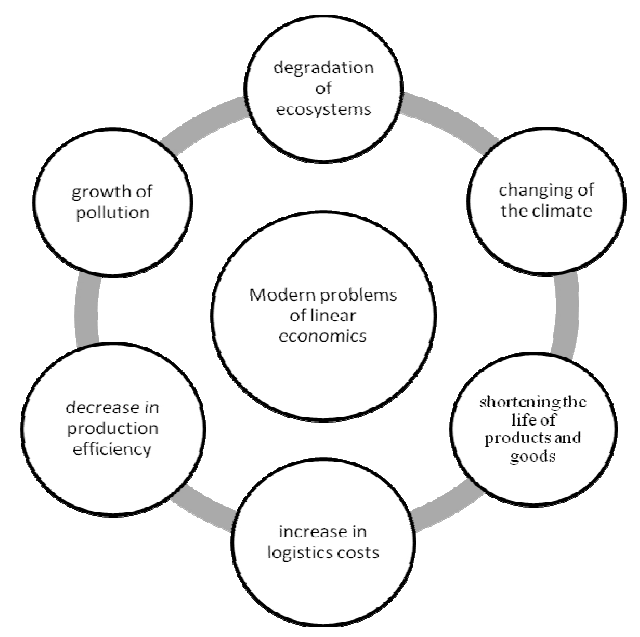

Fig. 1. Problems of linear economics

The circular economy differs from the traditional 3R concept of «Reduction», «Reuse» and «Recycle» and collects resources primarily at the stage of purchasing raw materials and 
product design. It aims for zero waste when reused. For example, the maximum possible exclusion of the use of primary materials; the introduction of a disassembly-based module design so that it can be easily reused and recycled after collection, as well as maximizing product life by repairing and replacing parts, is a commitment to circular resource use [12].

The Ellen MacArthur Foundation, a well-known international agency for the development of a closed economy, identifies the following three principles of a closed economy (Figure 2).

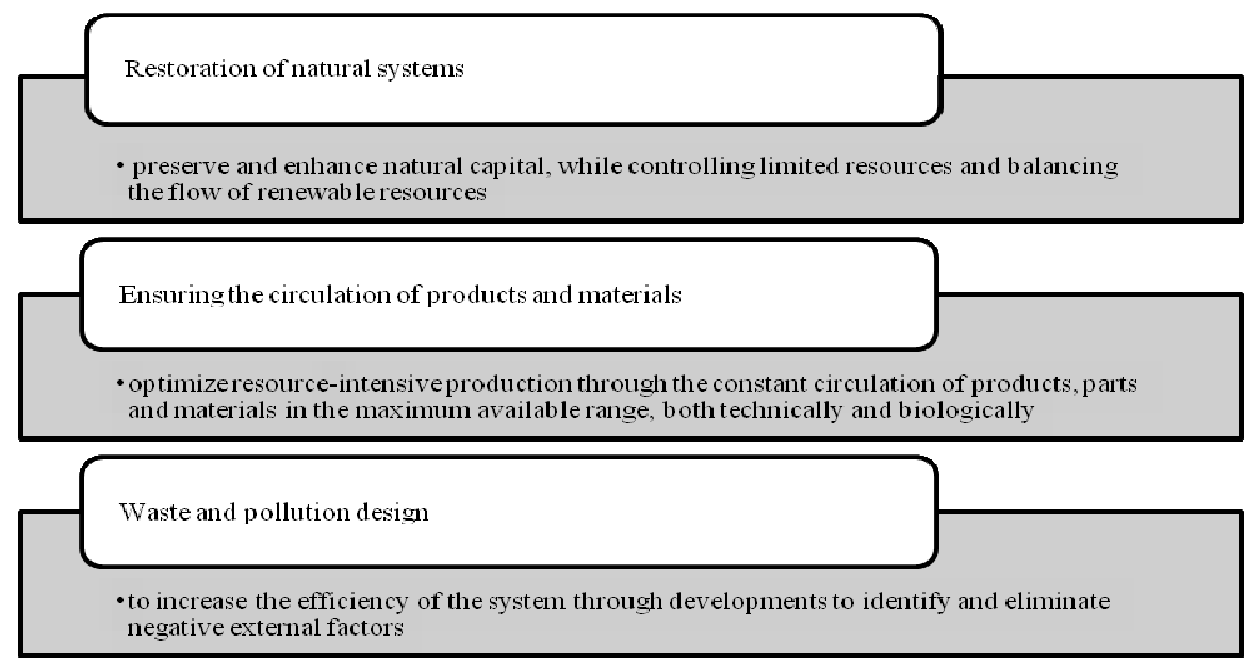

Fig. 2. Principles of a circular economy

At present, the following classification of business models of a closed cycle of the economy can be distinguished (Fig. 3).

Let's see how they are used in practice. Energy production can be used in a loop where excess energy from cooling systems is used to supply residential buildings with district heating. Another example is a combination of wastewater treatment, the use of treated wastewater for irrigation purposes, and the reuse of (dried) sewage sludge to produce charcoal. Online community platforms such as sharing platforms that allow more people to come together for a ride, rather than traveling in a private car. This reduces the cost of travel, reduces traffic and reduces $\mathrm{CO}^{2}$ emissions. Other examples are the processing of construction waste and its use for insulating buildings; design of biodegradable food packaging [13].

MoBiol Algae Research Institute launches a business in Indonesia to treat palm runoff using microalgae and DHA (docosahexaenoic acid) extract. This will help to address the environmental burden of liquid palm waste, increase the profitability of palm owners and protect marine resources. [14]

Ikea has announced that it is moving to a furniture leasing business model. Citroen has introduced a small and inexpensive electric car Ami One, which does not plan to sell. The car will only be available for the car sharing or leasing model. Zewa has started using renewable fibers in all its products. It is now recycled fiber or wood fiber from FSC or PEFC certified sources. An alternative resource fiber is being developed from wheat straw, which is a by-product of agriculture. As for packaging, by 2025 it is planned to reach $100 \%$ recycling and use $85 \%$ of renewable or recycled materials [14]. 


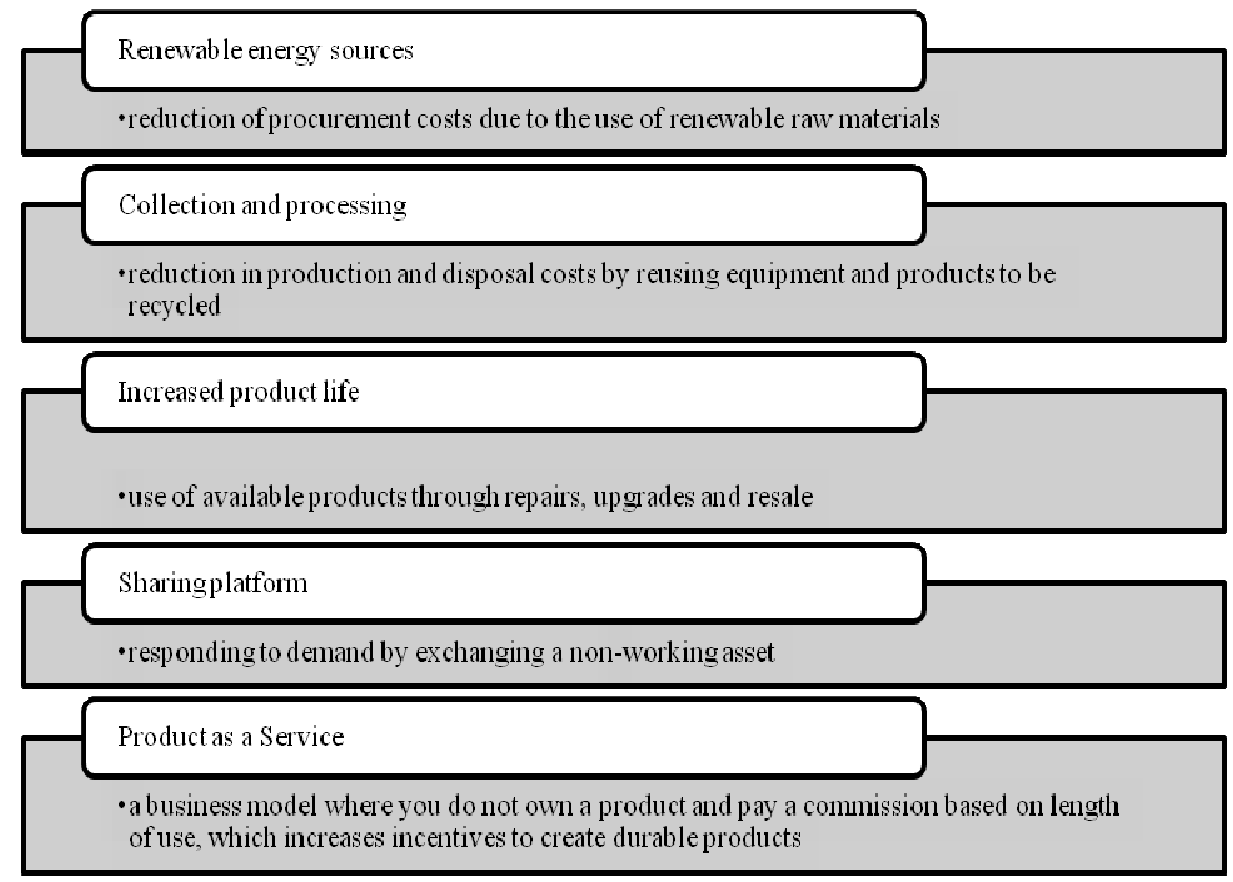

Fig. 3. Possible models of the circular economy

\section{Results}

Accenture estimates the circular economy market will grow to $\$ 4.5$ trillion by 2030 . On the other hand, Juniper Research estimates the market size of the sharing economy to be $\$ 40.2$ billion by 2022 [14].

In December 2015, the EU adopted a Circular Economy Package entitled "Ambitious New Measures to Improve Competitiveness, Job Creation and Sustainable Growth". The circular economy package includes 550 million euros from the European Structured Fund (ESIF), 650 million euros from the EU Research and Development and Innovation Program. Many governments and local governments have already made the circular economy an axis of national policy, and are making efforts on a wide range of economic, environmental and social dimensions (Figure 4). 

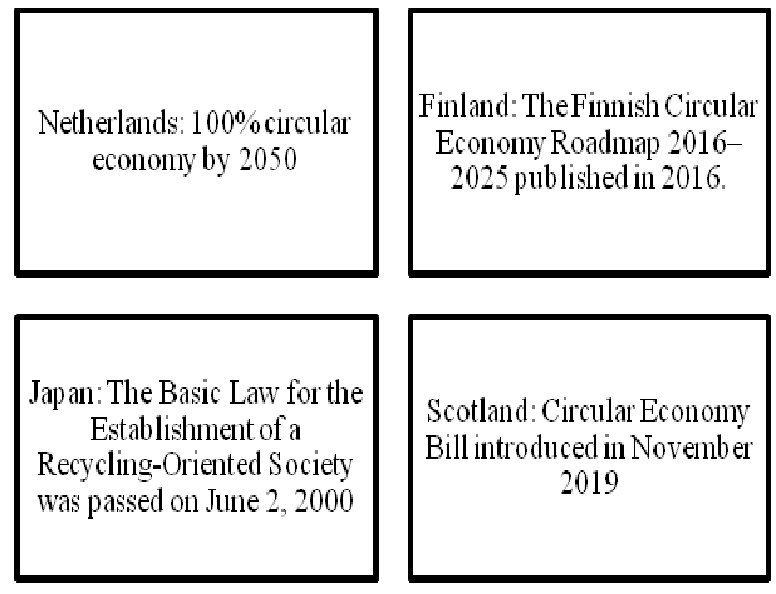

France: France's Closed Economy Roadmap: 50 Measures for a $100 \%$ Circular Economy

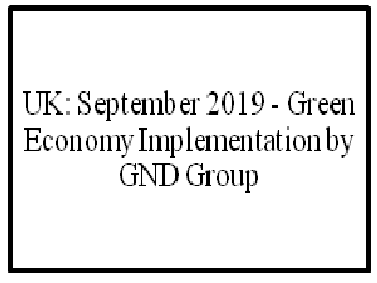

UK: September 2019 - Green GND Group
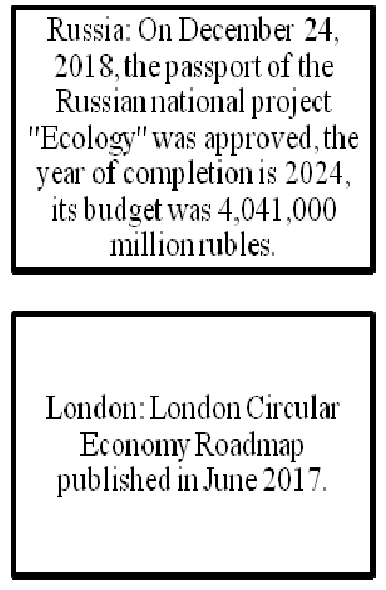

Denmark: in September 2018, the government presented its strategy for the development of a circular econony

Fig. 4. Examples of countries adopting a circular economy model

And special benefits can be gained for low- and middle-income countries. International Resource Panel simulations show that global resource use growth could slow by $25 \%$ by 2060 with the right sustainable policies. Meanwhile, global GDP could grow by $8 \%$, with particular benefits for low- and middle-income countries.

I would like to separately note the Russian practice. In 2018, the 300 largest Russian enterprises (oil and gas, metallurgical) are switching to the best and most affordable technologies (BAT). And by 2021, all Russian enterprises should switch to these technologies. «We have a pyramid of priorities for what to do with waste. In the first place is the reduction in the consumption of raw materials. The second is to reduce waste generation. The third is utilization, and somewhere a secondary resource may appear, which will be involved in circulation. Next comes the incineration as a type of disposal. In an extreme case, burial at landfills», - noted Viktor Evtukhov, State Secretary - Deputy Minister of Industry and Trade of the Russian Federation [15].

Today, there are two main directions for promoting the principles of a circular economy: through large companies and governments. Small and medium-sized businesses, due to their limited resources and market share, can only support the existing trends in society. The production activities of large TNCs cover the entire technological chain from the supply of materials to the sale of goods; it is easier and more profitable for them to implement pilot projects that comply with the principles of a circular economy. Such projects change the role of the consumer and turn him into a user: the product is used, and at the end of its service life, it is returned to the manufacturer, who can release a new model based on it or create another product using old materials.

\section{Discussions}

In this case, the position that innovations in the field of green technologies can have a return only for high-income economies seems to be of fundamental importance. This 
circumstance is reinforced by the opinion that the state policy of poor countries is largely focused on improving the quality of life of citizens, and not on solving environmental problems [16]. Note that the problem of inequality of countries is also relevant when considering various aspects of integrating Industry 4.0 technologies with the practice of introducing a circular economy on a conceptual basis [17].

Within the framework of UN documents, the concept of a green economy is a key link for the transition to a sustainable development model. It is the green economy, according to some researchers, that is the key to the formation of an effective economy, and therefore the achievement of sustainability depends entirely on its timely and high-quality implementation into the existing economic model [1]. The global scale of the "green" orientation of development is emphasized by the importance of state support and, possibly, the need for a radical restructuring of approaches to the national development of a number of countries [18].

At the same time, scientific research notes the possibility of long-term development without adopting a single global strategy that provides for an orientation towards making "green" decisions. In particular, the experience of Poland is cited as an example. In the absence of a political strategy to promote a circular bioeconomy, innovations are actively used, in particular, in the biogas industry [7].

The issue of combining green technologies with smart technologies requires special attention. In particular, there is no consensus regarding the environmental friendliness of innovations used in the construction of smart buildings, the formation of a smart urban environment, and the active introduction of digital technologies. The latter position is especially controversial from the point of view of preserving the health of users of smart services, since the digitalization of living space involves limiting the physical activity of citizens and their social activity outside information networks [19]. Circularity is merely a means to the goal of reducing environmental pressures, and returning to that goal, it is pointed out that there is a more effective approach than seeking to improve enclosure. The circular business model is more expensive than the traditional linear business model of the economy type, and there is no incentive for companies and consumers to make circular choices, therefore political intervention is necessary [14, 20]. Such support can be provided through the provision of research grants, provision of tax incentives and priority in public procurement; and increased taxes on waste disposal.

So, let's summarize all the opinions "for" and "against" the introduction of a circular economy (Table 1)

Table 1. Advantages and disadvantages of the circular economy concept

\begin{tabular}{|c|c|}
\hline Advantages & Disadvantages \\
\hline $\begin{array}{l}\text { Promotes economic growth and resource } \\
\text { conservation through a closed system } \\
\text { Circularity is a means of reducing the } \\
\text { burden on the environment, not a goal. }\end{array}$ & $\begin{array}{l}\text { Circularity is a means of reducing } \\
\text { environmental stress, not a goal. }\end{array}$ \\
\hline $\begin{array}{l}\text { Covers all activities aimed at reducing, } \\
\text { reusing and recycling materials and creates } \\
\text { numerous new economic opportunities } \\
100 \% \text { - circular economy is impractical and } \\
\text { not optimal. }\end{array}$ & $\begin{array}{l}100 \% \text { - circular economy is } \\
\text { impractical and not optimal. }\end{array}$ \\
\hline Advantages & Disadvantages \\
\hline $\begin{array}{l}\text { Has enormous potential for broader positive } \\
\text { environmental and social impacts The }\end{array}$ & $\begin{array}{l}\text { The market ignores externalities } \\
\text { and the circular economy has no }\end{array}$ \\
\hline
\end{tabular}




\begin{tabular}{|c|c|}
\hline $\begin{array}{l}\text { market does not take into account } \\
\text { externalities and the circular economy has } \\
\text { no competitive advantage. }\end{array}$ & competitive advantage. \\
\hline $\begin{array}{l}\text { Minimizes all types of losses by } \\
\text { transforming them into a new resource } \\
\text { Government measures are needed to } \\
\text { increase the competitiveness of the circular } \\
\text { economy. }\end{array}$ & $\begin{array}{l}\text { Government measures are needed } \\
\text { to improve the competitiveness of } \\
\text { the circular economy. }\end{array}$ \\
\hline $\begin{array}{l}\text { Job Creation, Implementation, Innovation } \\
\text { and Productivity Growth The circular } \\
\text { business model is more expensive than the } \\
\text { traditional linear business model, the } \\
\text { economy type, and there is no incentive for } \\
\text { companies and consumers to opt for it. }\end{array}$ & $\begin{array}{l}\text { The circular business model is more } \\
\text { expensive than the traditional line } \\
\text { economy business model, and there is } \\
\text { no incentive for companies and } \\
\text { consumers to opt for it. }\end{array}$ \\
\hline
\end{tabular}

\section{Conclusion}

The circular economy model is part of the ongoing fourth technological revolution. The result of the introduction of this model will be an increase in the rational use of resources, the transparency of the economy, its predictability and the acceleration of the pace of economic development. At the same time, a different perception from society is required all human actions must become more rational, it is necessary to change the culture of consumption.

Wherever you live, circular transitions are critical to building a resilient economy, protecting social well-being, and mitigating the impact of the climate crisis. It can be especially important for middle-income countries given the impact on jobs and their particular vulnerability to the effects of the climate crisis.

\section{References}

1. R. A. Perelet, Environmental aspects of the digital economy, World of a new economy, 12(4), 39-45 (2018) DOI: 10.26794 / 2220-6469-2018-12-4-39-45

2. UN (2015) Transforming Our World: The 2030 Agenda for Sustainable Development. (Last accessed 11.12.2020) https://documents-dds-.un.org/doc /UNDOC/GEN/N15/285/75/PDF/N1528575.pdf

3. E. Avdeeva, O. Belyantseva, E. Smorodina, Proc. Int. Conf. on MATEC Web of Conferences Siberian Transport Forum - TransSiberia, 08004 (2018)

4. C. Sassanelli, P. Rosa, R. Rocca, S. Terzi, Circular economy performance assessment methods: A systematic literature review, Journal of Cleaner Production, 229, 440-453 (2019) DOI: 10.1016 / j .jclepro.2019.05.019

5. P. J. M. van Boerdonk, H. R. Krikke, W. Lambrechts, New business models in circular economy: A multiple case study into touch points creating customer values in health care, Journal of Cleaner Production, 282, 125375 (2021) DOI: 10.1016 /j.jclepro.2020.125375

6. S. N. Bobylev, New economic models and indicators of sustainable development, Economic Revival of Russia, 61(3), 23-29 (2019) 
7. P. Kaszycki, M. Glodniok, P. Petryszak, Towards a bio-based circular economy in organic waste management and wastewater treatment - The Polish perspective, New Biotechnology, 61, 80-89 (2021) DOI: 10.1016 / j.nbt.2020.11.005

8. M. A. Guryeva, Theoretical Foundations of the Circular Economy Concept, Economic Relations, 9(3), 2311-2336 (2019) DOI: 10.18334 / eo.9.3.40990

9. P. A. Nosko, Circular Economy Development Trends in the European Union, Waste and Resources Online Journal, 1 (2019) https://resources.today/PDF/04ECOR119.pdf DOI: 10.15862 / 04ECOR119

10. C. J. C. Jabbour, J. Sarkis, A. B. L. D. Jabbour, D. W. S. Renwick, S. K. Singh, O. Grebinevych, I. Kruglianskas, M. Godinho, Who is in charge? A review and a research agenda on the 'human side' of the circular economy, Journal OF Cleaner Production, 222, 793-801 (2019) DOI: 10.1016 / j.jclepro.2019.03.038

11. World Economic Forum https://www.weforum.org/ agenda / 2021/01 / why-middleincome-countries-should-embrace-circular-economy / (Last accessed 15.12.2020)

12. T. Davydova, E. Avdeeva, L. Kochetova, T. Makeeva, Proc. Int. Conf. on Competitive, Sustainable and Safe Development of the Regional Economy (CSSDRE 2019), 83, 204-207 (2019)

13. Y. Bondarenko, T. Azarnova, I. Kashirina, T. A. Averina, Aggregation Models and Algorithm for Coordinating the Interests of the Region and Enterprises of the Energy Complex. Advances in Intelligent Systems and Computing, 983, 69-78 (2019)

14. World Idea Magazine https://ideasforgood.jp/glossary/circular-economy/ (Last accessed 15.12.2020)

15. Russian Forum https://roscongress.org/sessions/ekonomika-zamknutogo-tsiklarossiyskaya-model-i-zarubezhnyy-opyt/discussion/ (Last accessed 15.12.2020)

16. P. Kautish, J. Paul, R. Sharma, The moderating influence of environmental consciousness and recycling intentions on green purchase behavior, Journal of Cleaner Production, 228, 1425-1436 (2019) DOI: 10.1016/j.jclepro.2019.04.389

17. D. L. M. Nascimento, V. Alencastro, O. L. G. Quelhas, R. G. G. Caiado, J. A. GarzaReyes, L. R. Lona, G. Tortorella, Exploring Industry 4.0 technologies to enable circular economy practices in a manufacturing context A business model proposal, Journal of Manufacturing Technology Management, 30(3 SI), 607-627 (2019) DOI: 10.1108/JMTM-03-2018-0071

18. H. P. Sun, B. K. Edziah, C. W. Sun, A. K. Kporsu, Institutional quality, green innovation and energy efficiency, Energy Policy, 135, 111002 (2019) DOI: 10.1016/j.enpol.2019.111002

19. E. A. Avdeeva, T. A. Averina, T. E. Davydova, E. N. Zhutaeva, Automation of Russian Industry as an Indispensable Condition for Sustainable Economic Development in the Digital Environment. IOP Conference Series: Materials Science and Engineering. Krasnoyarsk Science and Technology City Hall of the Russian Union of Scientific and Engineering Associations, 42041 (2020)

20. S. A. Barkalov, O. S. Perevalova, T. A. Averina, Development of the Algorithm for Maximizing the Financial Results of the Investment Program. Proceedings of 2018 11th International Conference "Management of Large-Scale System Development", MLSD 2018. P. 8551863 (2018) 